\title{
Learning servant leadership and identifying community-based strategies in times of divide: A student, faculty, community partner interfaith collaboration
}

\author{
Dr. Kristine Hoover, EdD \\ Associate Professor \\ Gonzaga University \\ Maggie Douglas \\ Graduate Student \\ University of Washington
}

\begin{abstract}
In times of deep political and religious division and limited resources, the need for developing leadership that influences and heals our communities is particularly critical. Using servicelearning, combined with community engaged scholarship, this pedagogical approach enhanced student transformation, involved and benefited the community growing together, and explored potential contributions to literature in servant leadership. The collaboration involved designing and planning a three-hour event and data collection to address combatting hate and creating greater compassion. Student, faculty, and community worked together in this independent project and reflections indicate significant efficacy of servant leadership in the interfaith community with actionable and accessible outcomes.
\end{abstract}

\section{Introduction}

The demand for leadership continues to be a strong and present need in our global society. At the 2017 Annual Meeting of the World Economic Forum, the chairman stated "We must never forget that we live in an interdependent world...If we recognize that we are all part of a global community, then we have to overcome our prejudices and work together in a practical fashion while genuinely respecting each other's identity and dignity" (Schwab, 2017). In business, Uber CEO explicitly acknowledged, "I need leadership help" (McGregor, 2017). Students across the country in business and public policy have written to the U.S. President asking for greater leadership to create jobs, businesses and benefits of clean energy (Holz \& Serrurier, 2017). In the complex contexts of economics, education, politics, religion, and multiple other forms of identity and worldviews, these are a small sample of the need to effectively develop a leadership pipeline and the necessity for continued innovation in relevant leadership education and development. As students begin to transition into global leaders, it is necessary leadership educators equip their students with opportunities to participate in leadership theories, so as to develop and refine the practice of students' leadership behavior through service learning. The learning outcomes for the innovative practice here were:

1. The student will be able to experience the deeper meaning of enacting servant leadership in the complex context of an interfaith dialog (Servant leadership elements of persuasion, conceptualization, foresight and stewardship) 
2. The community will be able to identify strategic actions to combat hate and create greater compassion as well as enhance their own motivation to act (Servant leadership elements of listening, empathy, healing, awareness, growth of people, and building community)

3. The student and faculty member will be able to study the community's perceived effectiveness of several servant leadership elements.

To be effective, leadership educators must design opportunities aligned with leadership learning outcomes, fundamentally grounded in leadership theory. The innovative practice described in this paper is particularly impactful in that it creates a more holistic learning experience (cognitive, affective, and behavioral) allowing the student to partner with the community and learn research methodologies. This pedagogy may also be known as undergraduate communitybased action research that contributes to the leadership needs of the community. In this student experience, the student was asked to stretch beyond her existing body of servant leadership knowledge and move into higher levels of critical thinking (Bloom, 1956) as related to complex challenges facing today's leaders. The student was also asked to participate in a version of learning that initially appeared uncomfortable and frustrating. The student in this innovative practice had been a large advocate against service-learning, and had actively avoided the practice throughout her undergraduate career (even so far as to waive the required service-learning component of her University's living-learning residential community). As this project did not appear as explicitly service-learning, the student voluntarily contributed to the innovative practice. Upon guided reflection with the leadership educator, the student was able to identify the indispensible value of service-learning as it relates to actively participating in leadership development.

In the midst of intellectual, secular conceptions and applications of servant leadership, servant leadership is often observed as a predominantly non-secular approach to leadership theories and practices. As religious foundations serve as the basis for which individuals interpret and categorize the world around them, theories of servant leadership must be accessible beyond any one singular space. For a higher education system to situate itself in such a way to cultivate interfaith dialogue in the community surrounding, the benefits of servant leadership must be applicable beyond the predominantly non-secular spaces.

As such, the authors identify servant leadership, as practiced through service-learning, the central access point for students to understand and respond to society's deepest needs. With the focus of interfaith servant leadership, it is critical for a campus-community partnership to flourish for community members to access neutral spaces and abundance of knowledge and resources. Simutaneously, interfaith servant leadership for students to tap into places of deep fear and anxiety in the community, and reach out with the intention of serving to develop the followers' understanding of empowerment and success.

\section{Review of Related Scholarship}

Service-learning models originate in the values of "connect[ing] both disciplinary learning and generational education with...commitment to public purposes" (Felton \& Clayton, 2011). In order to separate from the traditional understanding of education as a "process where an individual receives or gives systematic instruction" (Bugenhagen, 2015) educators must 
demonstrate the desire to integrate civic engagement with academic learning. As service-learning evolves into a popular pedagogical approach, the experiences of these practices emerge with a focus around three central themes: advanced learning goals, reciprocal collaboration, and critical reflection (Felton \& Clayton, 2011).

The transition from traditional education to service-learning models of learning comes with the "action of acquiring new, or modifying... existing knowledge, behaviors, skills, values, or preferences as well as synthesizing different forms of education" (Bugenhagen, 2015). This nuanced interaction with knowledge is then put into conversation with civic learning and personal growth. Learning processes and outcomes shift towards an interdependent relationship with community processes and outcomes, and students experience strong correlations between their service-learning experiences and "deep learning and personal development" (Felton \& Clayton, 2011).

Felton and Clayton's (2011) service-learning research reports students with high exposure to service-learning have higher likelihood of being open "to diverse perspectives and ways of being... and understand more fully the true complexity of social problems." As a consequence, these experiences expose students to the opportunity to develop enhanced empathy, and as a result of their experience, be more likely to practice civic engagement in the community around them.

The employment of service-learning, then, can open the door to practicing theories of servant leadership and strategic learning. Greenleaf's theory of servant leadership, as understood by Larry Spears, challenges leaders to "emphasize increased service to others, a holistic approach to work, promoting a sense of community, and...sharing of power in decision making" (Greenleaf, 2002). Service-learning, then, becomes a fertile option to learning and practicing servant leadership. Larry Spears (2002) identifies ten characteristics of servant leadership to be "of critical importance" to the practice: listening, empathy, healing, awareness, persuasion, conceptualization, foresight, stewardship, commitment to the growth of people, and building community. Although the link between service-learning and servant leadership may seem natural, the pedagogy of service-learning would be incomplete without the practice of "reflection, discussion, analysis, and evaluation of that experience" (Polk, 2013).

Strategically, service-learning will thrive in an environment that supports "substantive change in their organizations and communities" (Langone, 2004). Practicing service-learning in a strategic way requires the organization to examine the "environment and the organization's mission or purpose and making decisions about which visions, activities, and goals to pursue” (Langone, 2004). Making an explicit connection between a service-learning environment and civic engagement enhances a student's ability to create and sustain real change. It is necessary to have a strategic understanding of service-learning in an educational setting to encourage practices of servant leadership and community dialogue.

Eboo Patel (2015) describes the crisis of rapidly changing religious dynamics for higher education institutions, as "prime sites for conflicts involving religious identity." How then, may we place the call for interfaith excellence in conversation with the service-learning and servant leadership? This education, Patel (2015) argues, must be based in empowering students to 
navigate "complexity, diversity, and change." Students in service-learning courses are positioned in an environment that has the possibility to not only nurture theories of servant leadership, but also cultivate civic engagement and interfaith service far beyond the academic setting.

\section{Description of the Practice}

Responding to a request from a community partner, faculty and students from one of the University's research institutes engaged to coordinate an event centered around the Interfaith Compassion Games "Souper Bowl Sunday." The initial goal of the event was to "perform compassionate service" as well as "establish/strengthen personal interfaith connections" (J. Broeckling, personal communication, January 19, 2017).

With the intention of being mindful to the multiple faiths represented at the event, it was essential the date of the event not in conflict with any major religious holidays. University resources to host an event with approximately 80 people were assessed. The student, community partner and faculty member reviewed advertising, communications, and risk management issues. The design of the "Souper Bowl" encouraged attendees to bring crockpots of soup and or canned goods to donate.

The student coordinated with student organizations that had a vested interest in promoting the event; the student coordinated with groups such as the Jewish club, various student faith groups, and multicultural education and community outreach offices. The faculty member coordinated with peers to offer additional class learning opportunities, and distribute information to other courses. The community partner coordinated efforts with the faith community. Each partner invited and tracked participation with a RSVP list on social media, and distributed emails amongst their interest groups. The budget was restricted to $\$ 100$ (supported by academic program), and the budget was spent entirely on space reservation.

Although the community partner and student facilitated the three-hour event, there was no "guest speaker" per se. The event was held on a single evening and separated into three sections: meal, building relationships, and dialogue. During the meal, participants were encouraged to sit with those that practiced faith differently, and have conversations. During the "building relationships" segment, participants physically built different forms of bridges at their tables with the donated cans of food and a stack of cards. For the last portion, participants first conversed about the manifestations of fear and hate in their communities and ways in which they actively combat related actions, followed by a request to complete a survey.

\section{Discussion of Outcomes}

There were three specific learning outcomes for this innovative practice. The first was deepening the student's understanding of servant leadership in a complex context. The second was the community's identification of strategic actions to combat hate and create greater compassion as well as enhance their own motivation to act. And the third involved the community-engaged scholarship. 
For the student, the learning focused on persuasion, conceptualization, foresight and stewardship as elements of servant leadership (Greenleaf, 2002). During the initial discussions regarding the event, as a student working with community leaders and University administration, the student practiced persuasion, which was required given the inherent differences positional power. Persuasion was involved with identifying a date, location, advertising and food logistics.

In the practice of conceptualization, the event was designed to stretch beyond a single night of "breaking bread" together, and included intentional listening, empathy, healing, awareness, growth of people, and building community (Greenleaf, 2002). The opportunity to learn and grow in the area of foresight was evidenced in many ways. The University had several risk management concerns. Multiple crockpots using the outlets in one space was an immediate flag for risk management, the concern being focused around safety hazards for attendees and students. Additionally, concerns were raised because of warm food would be exposed for more than one hour, and unpredictability of food prepared outside a commercial kitchen. As challenges with University policies and procedures increased, the organizers were presented with an opportunity to re-conceptualize and move beyond the "day-to-day focused approach" (Greenleaf, 2002) of leadership solutions.

The lesson of foresight was amplified due to these circumstances, as a search for new space was initiated for conference rooms in local libraries, community centers, and other nondenominational and non-political gathering spaces. Challenges of open space as well as funding limitations surfaced. Cancelling the event was an alternative of last resort, and a true commitment to stewardship was tested. The stewardship learning outcome also became evident when the event was eventually located at a community center in one of the lowest income neighborhoods in the state. In addition, the day of the event brought snow, and with it, many of the elderly participants were unable to attend. The student practiced strategic leadership throughout the event, as she evaluated the needs of the organization, and aligned it with the capacity of the event. Fostering the value of stewardship in the midst of internal and external challenges, thirty adults and children brought soup and other foods to enjoy. Of the thirty attendees, thirteen surveys were collected. The event concluded at the end of the three-hour segment with warm embraces and exchanges of contacts.

For the community partner, growth occurred in the servant leadership areas of listening, empathy, healing, awareness, growth of people, and building community. Specifically, the evening's agenda included eating together, building relationships, and dialoguing where these skills could be practiced. Community members began to conceptualize the needs of their own communities, and the communities of others. The Jewish woman's experience of learning Arabic sentences to listen and speak with her Islamic neighbor showed insight for how she may not only meet her neighbor in her own experiences, but also show the willingness to heal deep divisions. The partnership between the University and interfaith organizations not only empowered those involved with the organization of the event to build community, but the attendees as well, as they participated in deconstructing preconceived barriers by simply starting a conversation.

The third learning outcome was community-engaged scholarship. At the conclusion of the event, a one-page pencil and paper was administered as a means of collecting data on the evening. Wording on the survey reframed aspects of servant leadership with the intention of measuring 
responses to behaviors, and to respect that some faiths may have preconceptions of the theories of servant leadership. The results of the exploratory study allowed a lens for which the university and the community could recognize and serve the needs of their communities. Among the 13 respondents, $46 \%$ were female, $15 \%$ were male, and $23 \%$ were other, or preferred not to answer. The ages of those who responded ranged from 32 years of age to 70 years of age. Faiths and worldviews present were Agnostic and/or Toltec, Islam, Unity Church, Jewish, and Catholic. Both quantitative and qualitative data were collected. Participants were asked to rate responses to the question "How effective are each of the strategies for you in combatting hate?" and to provide examples of various forms of servant leadership behaviors. Ratings were based on a scale of 1 to 5 with 1 being not very effective and 5 being very effective. Average scores were: Learn to enjoy small talk more (listening) 4.18; Give compliments (empathy) 4.18; Open up to people (healing) 4.45: Think of all the ways people can help you (awareness) 4.0; and Volunteer (growth and building community) 4.78. Two open-ended questions were asked: "What was a significant lesson you will take away from this event?" and "What is a recommendation you would make to improve events like this in the future?" Participants indicated they felt inclined to volunteer more often in their community and open up to others, as their experiences provided an avenue for which they may "take a chance" and understand "how easy it is to connect" with one another.

\section{Reflections of the Practitioner}

This innovative practice was a result of collaboration by student, faculty, and community partner. Reflections of the practitioners mirror those that organized the study.

The opportunity to strategically engage with the student's undergraduate education, beyond spaces of campus, encouraged the exploration of possibilities when applying knowledge. When conversations among organizers seemed unoptimistic, all parties looked to align themselves with the understanding of a similar mission: success for all involved. With this recognition, navigating the University's policies became less of a combatant search for answers, and instead a strategic pursuit of opportunities for the interfaith community. The surge of confusion with licenses and risk management left little time to consider best options. As the student had the opportunity to speak more with community members who were to attend, it became increasingly obvious the need wasn't necessarily to find a campus space, but rather, a space of neutrality in the midst of polarization.

The opportunity to align actions with both the University community and the interfaith community presented a unique opportunity: the student's service-learning did not necessarily require her to practice servant leadership for one community, but rather, for each communities involved. As the student listened to the needs of those involved, she was encouraged to "put followers first" and listen with intention and authenticity to the needs of others. Consequentially, the team refocused the location of the event with little difficulty.

The student valued her service-learning because of the challenge to practice servant leadership theories in both secular and non-secular spaces. Her comprehension of Robert Greenleaf's theories on servant leadership redefined itself through the ability to move servant leadership away from a predominantly Christian setting, and instead to interfaith and secular spaces. 
This experience provided learning opportunities and benefits in both intended and unintended ways. In addition to the stated objectives, the student, community partner, and faculty member also exercised skills in adaptive leadership, with unforeseen aspects of scheduling procedures, risk management, initial misunderstanding of community needs, and weather concerns. This innovative practice effectively placed the student, community partner, and leadership learning objectives first - in contrast to a traditional faculty "sage on the stage" approach. Through the event planning and implementation, the student, community partner, and faculty practiced the embodiment of servant leadership, encouraging the leadership necessary for a civil, democratic society. The survey was an integral aspect of the event, in that it provided a basis for scholarship, and just as importantly provided a mechanism to empower the interfaith community to reflect and generate strategic and accessible action steps.

\section{Recommendations}

Moving forward with a deeper understanding and awareness for service-learning opportunities, we recommend a component of similar experiences for students at least once during their tenure at their undergraduate institution. The student's conceptualization of organizing and participating in the community has shifted away from transactional exchanges, to an understanding of collaborating with the community for common good. The intense preparations before the event not only challenged the student's perceptions of working with and serving others, but it also encouraged the development of service beyond the University community.

This service-learning opportunity was independently driven; there were no requirements for action from any class syllabi or professor. As such, the service-learning opportunity was guided outside of an academic setting, but brought together by the guidance of the faculty member and director for the Institute of Hate Studies at the University. By incorporating the support and guidance of a senior faculty member, the student's experience of servant leadership and servicelearning went beyond the scope of volunteerism. Instead, because the faculty member was attune to the growth and development of the experiences as an undergraduate student, the faculty member reviewed experiences to derive academic and personal meaning. As such, the student's learning went beyond the lessons of how to navigate university policies, and instead focused on the strategic enhancement of community and civic engagement.

As a consequence, our recommendation resides in the ability for the faculty member to encourage and challenge the experiences of their students, regardless if the experience is spurred by a syllabi. The ability for the faculty member at the University to test the limitations of learning for the event provided the student the opportunity to engage with her own experiences as they pertain to the overall development of the human person. It is vital to continue and strengthen educational experiences so we may equip students with the tools and resources to address society's deepest needs. 


\section{References}

Boyer, E. L. (1990). Scholarship reconsidered: priorities of the professoriate. San Francisco, CA: Jossey-bass.

Boyer, E. L. (1996). The Scholarship of Engagement. Journal of Public Service \& Outreach, 1(1), 11-20. Retrieved March 2, 2017.

Bloom, B. S. (1956). Taxonomy of educational objectives. New York: David McKay Co Inc.

Bugenhagen, M. (2015). From the Guest Editor's Desk. Retrieved March 1, 2017, from http://www.journalofleadershiped.org/index.php/issues/vol-14-iss-4/413-from-the-guesteditor-s-desk

Greenleaf, R. K., Spears, L. C., Covey, S. R., \& Senge, P. M. (2002). Servant leadership: a journey into the nature of legitimate power and greatness. New York: Paulist Press.

Felten, P., \& Clayton, P. H. (2011). Service-Learning. New Directions for Teaching and Learning, 128, 75-84. Retrieved March 2, 2017.

Holz, K., \& Serrurier, B. (2017, January 18). Tomorrow's Energy Leaders Call for Leadership From Trump Today. Retrieved March 1, 2017, from https://www.greentechmedia.com /articles/read/tomorrows-energy-leaders-call-for-leadership-from-trump-today

Huang, H. B. (2010). What is good action research? Why the resurgent interest? SAGE Publications, 8(1), 93-109. Retrieved March 2, 2017.

Langone, C. A. (2004). The Use of a Citizen Leader Model for Teaching Strategic Leadership. Journal of Leadership Education , 3(1), 82-88. Retrieved May 1, 2017, from http://www.journalofleadershiped.org/attachments/article/58/JOLE_3_1_Langone.pdf

McGregor, J. (2017, March 1). Uber's CEO says 'I need leadership help.' What should it look like? Retrieved March 1, 2017, from https://www.washingtonpost.com/news/onleadership/wp/2017/03/01/ubers-ceo-says-i-need-leadership-help-what-should-it-loo

Patel, E., Baxter, K. B., \& Silverman, N. (2015). Leadership Practices for Interfaith Excellence in Higher Education. Liberal Education, 101(1/2), 48-53. Retrieved March 1, 2017.

Polk, D. M. (2013). Cultivating Self-Awareness with Team-Teaching: Connections between Classroom Learning and Experiential Learning. Journal of Leadership Education , 12(2), 122-135. Retrieved March 1, 2017, from http://www.journalofleadershiped.org/attachments/article/305/Polk.pdf

Schwab, K. (2017, January 10). A call for responsive and responsible leadership. Retrieved March 1, 2017, from https://www.weforum.org/agenda/2017/01/a-call-for-responsiveand-responsible-leadership/ 


\section{Author Biographies}

Kristine Hoover, Ed.D. is an Associate Professor of Organizational Leadership at Gonzaga University. She received her Master of Business Administration, Master of Organization Development, and Doctorate of Leadership Studies from Bowling Green State University. Dr. Hoover's research focuses on applied ethics, diversity, and service learning.

Maggie Douglas is a current graduate student at the University of Washington Evans School of Public Policy. She received her undergraduate degrees in Political Science and English Literature from Gonzaga University. She has presented her leadership research at the International Leadership Association (ILA) and Association of Leadership Educators (ALE) Conference. 